\title{
Raising Islamic Values tradition on the reading of Anbiya book
}

\section{Mengangkat nilai-nilai tradisi Islam dalam pembacaan kitab Anbiya}

\author{
Arik Cahyani* \& Eny Kusdarini \\ Department of Pancasila and Civic Education, Graduate Program, \\ Universitas Negeri Yogyakarta \\ Address: Jalan Colombo 1, Caturtunggal, Sleman, Special Region of Yogyakarta 55281 \\ E-mail: arikcahyani.2018@student.uny.ac.id
}

Article History: Received 9 January 2021; Accepted 2 July 2021; Published Online 10 July 2021

\begin{abstract}
Indonesia is a country with a diversity of cultures, ethnicities, religions, races, and traditions. In Indonesia, there are many combinations of cultural values and religious values that are used to elevate the values of a religion. In 2010, the Sheikh Subakir Association was formed as one of the Anbiya book reading associations in Blitar. This study aimed to determine the religious values in the tradition of reading the Anbiya book in Nglegok Sub-district, Blitar Regency, East Java. This study used a qualitative research method with a descriptive approach. The data were obtained through direct observation, in-depth interviews, and data collection with documents. The interviews were conducted with the head of the group, Sheikh Subakir, several group members, the secretary of the subdistrict, and village communities. Based on this research, it is found that there are eight values of the Anbiya book that invites humans to always do good in everyday life. The values in the contents of the Anbiya book include: faith values, Islamic values, perfection (ihsan) values, piety values, sincerity values, reliance (tawakal) values, gratitude values, and patient values. This study concluded that the reading of the Anbiya book is preserved to maintain cultural heritage and maintain Islamic values.
\end{abstract}

Keywords: Anbiya book; diversity; religious values; tembang macapat

\section{Abstrak}

Indonesia merupakan salah satu negara dengan keberagaman budaya, suku, agama, ras, dan tradisi. Di Indonesia banyak penggabungan dari nilai kebudayaan dan nilai keagamaan yang digunakan untuk mengangkat nilai-nilai suatu agama. Pada tahun 2010 dibentuklah paguyuban Syekh Subakir sebagai salah satu kelompok pembacaan Kitab Anbiya di Blitar. Penelitian ini bertujuan untuk mengetahui nilai-nilai religius yang terdapat dalam tradisi pembacaan Kitab Anbiya di Kelurahan Nglegok, Kabupaten Blitar, Jawa Timur. Penelitian ini menggunakan metode penelitian kualitatif dengan pendekatan deskriptif. Data diperoleh melalui observasi secara langsung, wawancara mendalam, dan pengumpulan data dengan dokumen. Wawancara dilakukan dengan ketua kelompok Syekh Subakir, beberapa anggota kelompok, sekretaris kelurahan, dan masyarakat desa. Dari penelitian ini diperoleh hasil bahwa terdapat sembilan nilai Kitab Anbiya yang mengajak manusia untuk selalu berbuat kebaikan dalam kehidupan sehari-hari. Nilai yang terdapat dalam isi Kitab Anbiya antara lain: nilai keimanan, nilai keislaman, nilai keihsanan, nilai ketakwaan, nilai keikhlasan, nilai tawakal, nilai syukur, dan nilai kesabaran. Studi ini menyimpulkan bahwa pembacaan Kitab Anbiya dilestarikan untuk menjaga warisan budaya dan mempertahankan nilai-nilai keislaman.

Kata kunci: Kitab Anbiya; keberagaman; nilai-nilai religi; tembang macapat

\section{Introduction}

Factual data prove that Indonesia has diverse tribes, cultures, religions, races, and traditions. From this diversity, cultural diversity is seen as the most prominent diversity in Indonesia (Ananta et al. 2016; Suradi et al. 2020). Therefore, it is not surprising that domestic and foreign tourists are interested in enjoying the show and adding their insights into this country's culture. From this diverse culture came up the hereditary tradition that exists in every society born from the pride and appreciation of generations on creation, cultural traditions of generations of its predecessors (Asfina \& Ovilia 2016). 
The word 'culture' itself comes from the word budh which in Sanskrit means reason, then it becomes the word budhi (singular) or budhaya (plural). Thus, culture is defined as the result of human thought or reason. Some argue that culture comes from the words budi and daya. Budi is an intellect which is a spiritual element in culture, while daya can be interpreted as an act or effort as a physical element. Therefore, culture is defined as the result of human intellect and endeavors (Soerjono 1982). According to Koenjaraningrat in Dayakisni \& Yuniardi (2004), a culture is a form that includes the whole of ideas, behavior, and the results of behavior. Meanwhile, tradition is understood as anything that has been passed down from generation to generation. Tradition in the anthropological dictionary is the same as custom, namely customs that are religiously magical from the life of an indigenous population, including cultural values, norms, laws, and rules that are interrelated. It becomes a system or regulation that has been established and includes all conceptions of a cultural system of culture to regulate human actions or actions in social life. Whereas in the sociological dictionary, it is defined as the belief in a hereditary manner that can be maintained (Burhan \& Asmiraty 2019).

Javanese society has many cultures that amaze many people who have survived to this day. Javanese culture has existed since the formation of Javanese society, which then grew and developed. A study shows that the people of Java have known a high culture in the stone age. In prehistoric times, the people of Java had known ten cultural elements before the spread of cultural influences outside Java Island. These elements include irrigated agriculture, batik, shipping, metrum (Javanese poetry stanza), astrology, puppetry, metal casting, currency, government system, and gamelan (Brandes 1901). In its development during the Dutch colonial era to maintain the King's authority is centered on cultural arts. The poets and masters of the palace order to make the artwork as beautiful as possible. For poets, the artwork is not only used to work but to get closer to the Creator. Because they have such a mental attitude, the resulting artwork is not beautiful based on observations using five senses but brightens the soul for those who enjoy it. In the field of literary art, in "the era of adoration", Javanese culture continues to grow and develop, expressing through macapat song (Sahlan \& Mulyono 2012).

In the culture of Nusantara, macapat song is an important part, especially in Java. This macapat song, with all its contents, has various functions, including as the messenger, means of speech, delivery of expressions of taste, the media depiction of the atmosphere, delivery of puzzles, da'wah media, educational tools and counseling, and so on (Sahlan \& Mulyono 2012). Macapat song can accommodate all these things, both express and implied content. As a message, macapat has its own characteristics and meanings based on its intended purpose (Suarta 2018). This can be interpreted that every single macapat song has its own purpose and meaning and different from each other which directly creates different messages (Syafitri et al. 2018).

According to Setiyadi \& Wiyono (2017), texts of macapat songs may contain expressions relevant to the development of cognitive systems and culturally pedagogical signs or piwulang in Java. These symbols are closely linked to character building as they may transform into religion, ethics, morality, and political orientation. This shows how high the express and implied value is in the macapat song. Not only these functions, since entering the Java Island, macapat song also began to be used as a da'wah medium for the spread of Islam. Da'wah was done by the preachers, especially those who were members of Wali Songo. Islamic preachers use art and culture as a da'wah medium to incorporate the teachings of Islam into society using something that has been liked by society all this time. The type of art commonly used by Wali Songo is puppet show art. Wali Songo changed the shape and content of the macapat song as a complement to the puppet show by composing it into religious, educational, and philosophical life (Sahlan \& Mulyono 2012). Nowadays, the macapat song is often performed in celebration of the big day as well as other events (Heriwati 2017).

Islam and Javanese culture have been assimilated since the golden age of Islamic kingdoms in Java. Islamic boarding schools (pesantren) were developed in vast numbers during the Demak and Mataram dynasties (Mu'adi \& Sofwani 2018). One example of this acculturation is found in Nglegok Sub-District, where the site of the Penataran Temple stood, the place of the maharaja of Majapahit-Brawijaya. The 
people of Nglegok Sub-district have a tradition of reading Anbiya book with sekar macapat. Sekar macapat is among the local wisdom in Javanese culture. It is regarded as noble wisdom closely tied to life in Javanese society (Saddhono \& Pramestuti 2018). The reading of the Anbiya book is an activity to read a book called an Anbiya book that has prophetic stories in Islam. However, the readers use macapat songs such as Pucung, Macapat, Dandang Gulo, Gambuh, Asmarandhana, Sinom, Kinanthi, Mijil, Megatruh. Maskumambang, Durma, Pangkur, and others.

In 2010, the Syekh Subakir Association was formed as one of the Anbiya book reading tradition groups in the Nglegok Sub-district. The people of the Nglegok Sub-district quickly accepted the Anbiya book reading tradition group. The development was very rapid, with frequent invitations obtained for reading the Anbiya book. The number of group members, which initially only six people, has reached twenty people from 2014 until 2019. This proves that there exists the Anbiya book reading tradition in Nglegok Sub-district and the community's spirit in the preservation of a huge tradition. So, it is interesting to study the amalgamation of Javanese culture and Islamic culture by explaining the historical background of the tradition of reading the Anbiya book carried out by the people of Nglegok Sub-district, Nglegok District, Blitar Regency. The traditional procedure for reading the Anbiya book is carried out by the community, and explores what religious values are in the tradition of reading the Anbiya book which is practiced in Nglegok Sub-district, Nglegok District, Blitar Regency. Therefore, this study aimed to determine the religious values in the tradition of reading the Anbiya book in Nglegok Sub-district, Blitar Regency, East Java.

\section{Research Method}

The method used in this study was a qualitative research method with a descriptive approach. This approach reveals the meaning and context of individual behavior and the processes that occur in the observed pattern of related factors (Moleong 2000). The research location was in Nglegok Sub-district, Nglegok District, because this is where the tradition of reading Anbiya books is proliferating. The community of Nglegok Sub-district can accept the entry of the tradition of reading Anbiya book well. To obtain accurate information, the researchers determined several data sources, including: 1) Syekh Subakir Association chairman (IMA); 2) several Syekh Subakir Association members (ABU, GUN, BAN); 3) secretary of Nglegok Sub-district (SOD); 4) a member of the community in the Nglegok Sub-district (MUL); and 5) documentation or written information about Anbiya tradition. The group members' selection was because the three members were the pioneers of establishing the Anbiya book reading tradition in the Nglegok Sub-district.

The researchers collected the data in three stages: 1) observation using participatory observation techniques by being directly involved in the daily activities of the research object; 2) in-depth interviews using semi-structured interviews by listening carefully and recording what the informants say, besides that the researchers conducted in-depth interviews using the language and terms of the local community; 3) the researchers went directly to the location and time of the Anbiya book reading tradition to collect data in terms of documents.

The data analysis activities were carried out in four parts: data collection, data reduction, data presentation, and conclusion/verification. 1) Data collection: an analysis was carried out before the data collection in the field and after the data collection. Before researching the field, the researchers conducted a study with a temporary research focus and performed the analysis at the time the data were collected and within a certain period after collecting the data; 2) Data reduction: the data obtained in the field were quite a lot, so the researchers reduced the data by summarizing and selecting the main points; 3) Data presentation: presenting the data in the form of a narrative by adding some documentation obtained during field research; and 4) Verification: tested existing assumptions or problems against the available data. 


\section{Results and Discussion}

\section{The Anbiya book reading tradition}

The Anbiya book tradition is a culture that wraps a message of religious knowledge in Javanese songs, so it is a high artwork with aesthetics that reflects society's high art appreciation. In that tradition, people are lead to have a compassionate attitude full of taste and love. It is proof that local people have a spiritual or immaterial culture. The reading of Anbiya book is also the result of creation, sense, and intention. The great aim is to form an entire society that is virtuous, dignified, upholding the function of art-culture, civilized-cultured.

The Anbiya book reading tradition comes from Surakarta, and the creator of the Anbiya book is Raden Ngebei Yasadipura I. He is a poet who used to live in the Surakarta Hadiningrat Kingdom. The language of the book used Kawi. Formerly, it used Arabic letters, but now it used alphabet letters. As for the Blitar Regency area, the Macapat Al-Ibrohimiyah Association, Mronjo Village, Selopuro District, Blitar Regency, became the first association that has printed the Anbiya book. KH Masyhadi Mufi (the chairman of the Macapat Al-Ibrohimiyah Association is one of those who took part in printing the Anbiya book in Blitar Regency, which was printed by the Al-Mubarok printing company. In addition to the purposes and activities of cultural preservation, some things are reasonably exciting and expressed by the chairman of the Anbiya book reading tradition group (IMA) as follows:

\footnotetext{
"The history of Anbiya book reading tradition has been written on every cover of Anbiya book. Created by Raden Ngabei Yasadipuro 1 in Mataram Praja Hadiningrat, which is now Solo City in Central Java, Anbiya then expanded rapidly to Blitar Regency. In Blitar Regency, the Anbiya book reading tradition was preserved by KH Masyhadi Mufi in the 20s century. He formed the AlIbrohimiyah Macapat Association in Mronjo Village, Selopuro District, Blitar Regency. From this point, the Anbiya book reading tradition develops to Nglegok Sub-district. The development in Nglegok Sub-district is quite rapid due to the interest of the large community. Although they didn't participate directly in this Anbiya book reading association, they were pleased and supported the existence of the Anbiya book reading tradition. For example, in 2010, the Anbiya book reading tradition association of Syekh Subakir consisted of 6 people. It rarely gets an invitation. More often, the Anbiya book reading tradition cash is insufficient for the group's movement. Therefore, members of the association often pay dues to cover expenses. But from 2014 until 2019, it has gained 20 members and often gets invitations from both individuals and government institutions. And the content of the event at the time of the Anbiya book reading tradition varies, there are thanksgiving, climbing prayers, and other religious events."
}

The difference between the Anbiya book reading tradition and macapat song is so prominent that the Anbiya book reading tradition dares to develop Megatruh music. When interpreted in Javanese, it comes from megat ruh, meaning to separate spirit or life. Meanwhile, the macapat song tradition association will think many times to create this Megatruh song. A member of the Anbiya book reading tradition association (GUN) said:

"In the Anbiya book reading tradition, it uses Megatruh song. This song can also be interpreted as two words: megat and ruh or separating life from the body. Whereas in the macapat song tradition, members of the association will think many times to develop Megatruh. The Anbiya book reading tradition thinks it is only Allah SWT who holds life and death. Thus, any song that is presenting in the Anbiya book reading tradition will not affect the life and death of the reader of the Anbiya book."

\section{Syekh Subakir association profile}

The Syekh Subakir Association chairman (IMA) initiates the Anbiya book reading tradition in Nglegok Sub-district. He is a community leader in Karanganom and Selorejo Hamlets. At first, he accidentally went to Mronjo Village, Selopuro District, to visit one of his siblings who gave birth. It turned out that 
there had been the Anbiya book reading tradition for a long time, and that was where he met one of the group members of Mronjo Village. From then, he was interested in the Anbiya book reading tradition. He liked what was in the Anbiya book. He then made a move by trying to find a way so that the tradition could also develop in Nglegok Sub-district. He invited his friends (GUN, ABU, and BAN) to establish an Anbiya book reading association.

In 2010, Syekh Subakir Association was formed as one of the Anbiya book reading tradition associations in the Nglegok Sub-district. Nglegok Sub-district people quickly accepted that community. The development was very rapid, with frequent invitations for the Anbiya book reading tradition association. The number of members, which initially only six people, has reached twenty people from 2014 until 2019. That proves that there exists the Anbiya book reading tradition in Nglegok Sub-district and the community's tremendous spirit in preserving tradition. Until 2019 the number of members of the Anbiya book reading tradition association in Nglegok Sub-district consisted of 20 people as follows: the chairman (IMA) and 19 members (GUN, MUS, JEM, LUG, SUK, BAN, ABU, KAM, TRI, BAR, HAR, JUN, MAS, MUT, BAD, DUK, ARI, FAU, and MUL). Of these twenty members, new members may preserve the Anbiya book reading tradition in Nglegok Village. Based on the information described by the chairman of Syekh Subakir Association (IMA), there is great hope to continue adding members and sustain this nation's noble tradition.

Syekh Subakir Association's vision is to build the nation's personality and create a generation with a noble character through religion. The mission of the Syekh Subakir Association is: 1) become a divinehuman being with the soul of the One Almighty God; 2) become a human being who is virtuous and loves religion; 3) the Indonesian nation and fellow human; 4) become a human being who is aware and obedient to carry out his obligations as a member of society or a citizen for the common interest and happiness.

\section{The Anbiya book reading tradition by Syekh Subakir association}

Anbiya book reading tradition is a traditional activity that is not yet well known by the wider community but has become a widely known tradition by Nglegok Sub-district society, especially the elderly. Even though the Anbiya book reading tradition activity cannot be separated from young people's participation as the next generation and cultural launchers, but the youth's role here is not optimal. As stated by a member of the Syekh Subakir Association (GUN):

"Anbiya book reading tradition activities in Nglegok Sub-district have very rapid development, even the support from various parties is very high. Especially from the government, it is effortless for us to get permission to hold the Anbiya book reading tradition activities. The youth here really respond to the activities of the Anbiya book reading tradition. However, on the other hand, it is difficult for young people to seriously explore the Anbiya book reading tradition, both the songs and its history. As evidence, many of the group members are old."

The Anbiya book reading tradition is scheduled according to specific days, for the Syekh Subakir Association holds the Anbiya book reading routinely on Tuesday night, Wednesday Legi (day in Javanese). They consider that the night is good for seeking knowledge and applying the knowledge they get. The Anbiya book reading tradition activity begins with an invitation from the residents or, as explained earlier, taking turns on each member of the Anbiya book reading association. The house owner where the Anbiya book reading tradition is holding starts everything by preparing all the necessities needed for the tradition, such as food, sound system, place, and others. Once the house's owner, where the Anbiya book reading tradition is carried out, has finished preparing everything for the Anbiya book reading activity, it will be started at 8.00 p.m. to 00.00 a.m. or midnight. However, Syekh Subakir Association members usually arrive at the Anbiya book reading place earlier, at 7.00 p.m. That is because the members have a conversation with each other and some train their skills in Javanese "gending" which will later be performed. 
Table 1.

Some examples of song lyrics in the Anbiya book reading tradition

\begin{tabular}{|c|c|c|}
\hline Song lyrics & Macapat song & Religious value \\
\hline $\begin{array}{l}\text { Niyat ingsun murwani amuji (My } \\
\text { intention is to praise), } \\
\text { lan anebut asmane Pangeran (And } \\
\text { call the name of God), } \\
\text { Ya Allah kang murba dhewe (O Allah } \\
\text { Almighty), } \\
\text { Rohman rahime tuhu (Most gracious } \\
\text { and compassionate), } \\
\text { Anrambahi sangya pra dasih (Who } \\
\text { promised us), } \\
\text { Puji patang prakara (Against four } \\
\text { things), } \\
\text { Wisesanireku, solawat salam tetepo } \\
\text { (I testify, prayers and greetings } \\
\text { continue), } \\
\text { Atas Nabi Muhammad syafiul khalqi } \\
\text { (To the Prophet Muhammad shafiul } \\
\text { khalqi), } \\
\text { myang pra uma sadaya (And to the } \\
\text { whole). }\end{array}$ & Dhandanggulo & $\begin{array}{l}\text { Belief in the existence of } \\
\text { Allah SWT and the Prophet } \\
\text { Muhammad, so that } \\
\text { humans will always try to } \\
\text { be good human beings }\end{array}$ \\
\hline $\begin{array}{l}\text { Sabar tiwas awak mami (Be patient } \\
\text { my child), } \\
\text { Yen kawona lawan simo (If you lose } \\
\text { against tiger), } \\
\text { Punapa ical otote (Why do you lose } \\
\text { your body), } \\
\text { Putra paduka sedaya (All son of me), } \\
\text { Nabi Yakub ngandika (The Prophet } \\
\text { Jacob said), } \\
\text { Lah gawanen bagus Yusuf (Bring } \\
\text { Joseph), } \\
\text { Nanging pama den kareksa (If it's } \\
\text { difficult). }\end{array}$ & Asmarandana & $\begin{array}{l}\text { Gratitude and reliance } \\
\text { (tawakal) values }\end{array}$ \\
\hline $\begin{array}{l}\text { Kang sima alon aturnya (The tiger } \\
\text { slowly announced), } \\
\text { Ila-ila amba gusti (Little by little, Your } \\
\text { Majesty), } \\
\text { Yen nedha-a putra tuwan (If you eat } \\
\text { your son), } \\
\text { Awak kawula puniki (This body of } \\
\text { mine), } \\
\text { Mugi-mugi njeng gusti (Hopefully } \\
\text { God), } \\
\text { Sampun manggih ing rahayu } \\
\text { (Already provides salvation), } \\
\text { Saturun-turun amba (To the } \\
\text { descendants of a slave), } \\
\text { Atur kawula njeng gusti (Set me up } \\
\text { for Lord), } \\
\text { Pan kawula kecalan anak setunggal } \\
\text { (Against my first child). }\end{array}$ & Sinom & Piety values \\
\hline
\end{tabular}




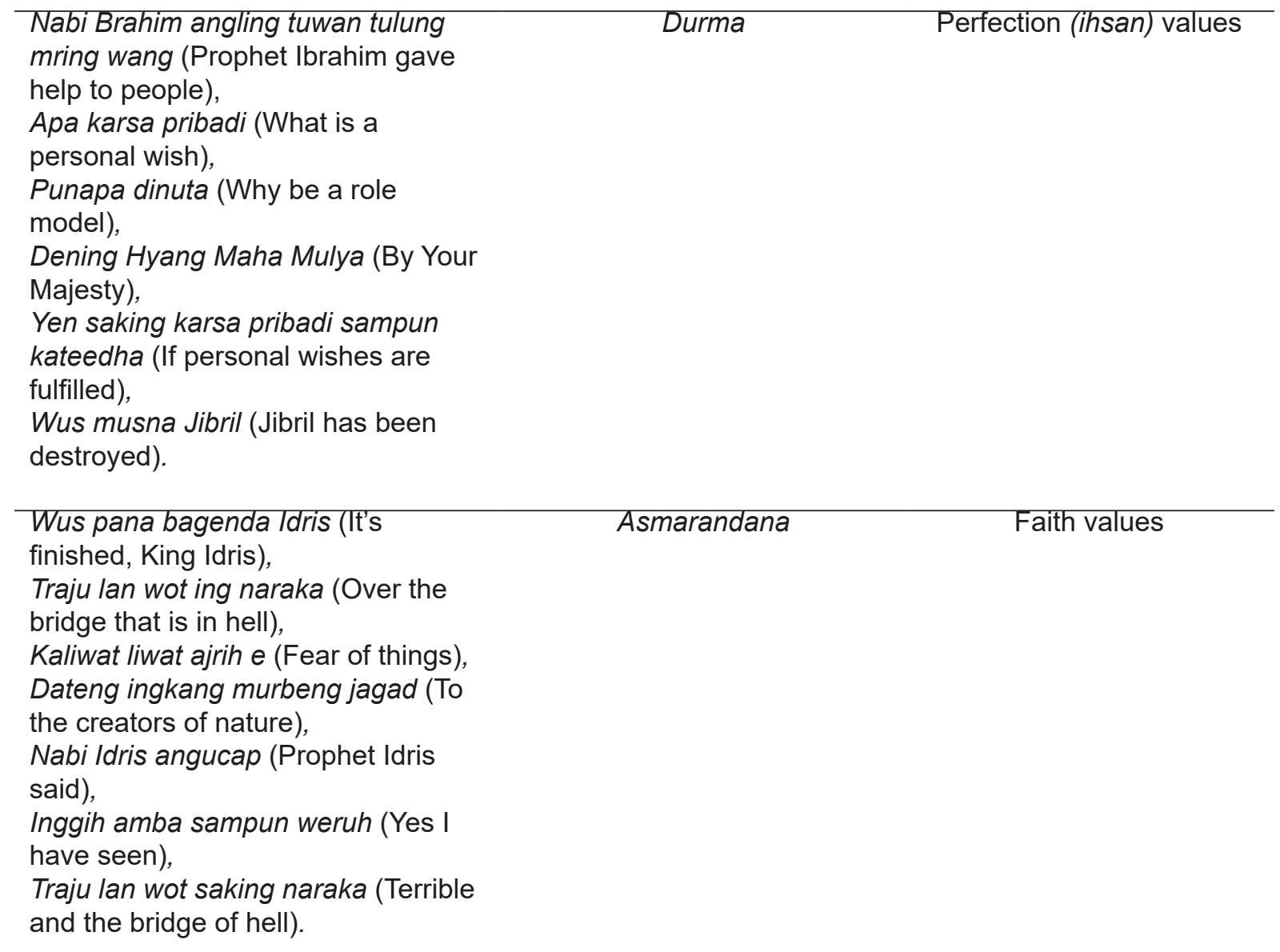

When all group members have arrived at the place and the time has shown 8.00 p.m., the Anbiya book reading tradition begins by reciting tahlil and sending prayers to the prophets, the prophet's companions, Wali Songo, and the scholars. Furthermore, prayers are addressed to family ancestors who desire, and all who have made the Anbiya book (Raden Ngabei Yasadipura I, KH Masyhadi Mufi, Hasan Kodri, and H. Syamsul Ma'arif). The reading of tahlil is carried out simultaneously and is a mandatory agenda in every Anbiya book reading tradition activity. Once the recitation of prayers and tahlil prayers is over, one of the group members determines the parts to read from each member present. The distribution of this reading material is carried out in a short time, after which the Anbiya book reading tradition begins according to the part of each member. This division is carried out so that there is no similarity in reading or overlapping the materials read between members during the Anbiya book reading tradition.

After the song distribution activity as well as reading material are completed, the Anbiya activity is continued with the core activity, in which each member of the Anbiya book reading tradition sings their part consecutively. The members read the Anbiya book one by one based on the Javanese song that has been written on each title. Some examples of song lyrics and their religious values can be seen in table 1 .

For the reading of verses in the Anbiya book, it is not to read as a whole for one night. The Anbiya book reading tradition is considered sufficiently until about 00.00 a.m. This is because reading all the Anbiya book will take much time. After reading the core of the Anbiya book, the activity continues with the manasuka song. Manasuka song is an entertainment song that is sung simultaneously or in turns. It is followed by ayak-ayak pamungkas, which is about prayer to be given mercy by Allah SWT. Besides, it ends with a three-time reading of istigfar, a compliment that reads: 
Gusti Allah kulo nyuwun ngapuro (God, I apologize)

Sekathahe duso kulo (All my sins)

Duso ingkang agung kelawan duso ingkang alit (Great sins as well as small sins)

Boten wonten ingkang saged ngapuro (No one can forgive)

Sanesipun ingkang Mahaagung (Except the Great One)

Kang ngaratoni sekathahe para ratu (Queen of queens)

Hiya iku gusti Allah asmane (The name is Allah SWT)

Kang kagungan sifat rahman (Who is loving)

\section{Religious values of Anbiya book reading tradition}

The Anbiya book reading tradition has very strong cultural and religious values, especially Islam. The Anbiya book does not only tells about the last prophet but also tells previous prophet stories. In the Anbiya book reading tradition, the religious values that are reflected are divided into two parts, which are at the opening and in the content section of the Anbiya book. There are a few essential religious values that have to be instilled in human life. The values which are essential include: a) iman (faith), b) Islam, c) ihsan (perfection), d) takwa (piety), e) Tawakal (reliance), f) syukur (gratitude), g) sabar (patience) (Madjid in Andewi 2016).

At the opening of the Anbiya book, there is a section called purwaka. Purwaka is a kind of foreword in most books, but in the Anbiya book, the purwaka tells gratitude to God Almighty. The gratitude is due to the existence of the Anbiya book as a means of worship, and it is still sustainable today. Besides, it also tells hopes and prayers for the Anbiya book reading tradition in the future, as well as prayers to the initiators and pioneers of this tradition. The rapid development of technology, electronic media, trade, politics, economy, and social affairs has changed the personalities of Indonesian society. This is the background of the Anbiya book reading tradition to make Indonesians have a religious character according to the content written at the opening of the Anbiya book. With this tradition, it is expected that it would be able to foster a generation of the nation with kind personalities as the primary human being. As written in the Anbiya book:

"Kridaning jiwanipun nuwuhaken tekad pari kedah cancut gumregut memangun kepribadening bangsa kangge utamaning budi pekerti serta nyetak generasi ingkang utami. (His soul's actions gave birth to the rice's determination to foster the nation's personality with character and to impress the primary generation.)"

Based on the purwaka of the Anbiya book, it is known that the Anbiya book and Anbiya book reading tradition are made and carried out based on a good purpose, a goal that reflects religious values and emphasizes the benefit of humankind. The invitation to benevolence is evident from the content and meaning at the opening of the Anbiya book. The result supports a statement from a member of the Syekh Subakir Association (BAN). He said:

\footnotetext{
"Anbiya book is not written based on entertainment only, but the contents have essential meaning, especially if it can be applied in everyday life. As humans in the modern era, sometimes we follow foreign cultures, which tend to be less effective when applied to our native culture, which is eastern culture. That is the background of reprinting the Anbiya book and forming the Anbiya book reading tradition association in various places. Da'wah, through Javanese music, is very effective in attracting public sympathy. Moreover, if we have read the Anbiya book to end, then apply it in everyday life, we will become an excellent primary human or human-like the one in ancient."
}

The Anbiya book tells the teachings of religious values using prophetic stories that are carried through the macapat song. This story can be simplified into eight religious values as explained by the Syekh Subakir Association chairman (IMA). He said: 
"The Anbiya book has eight religious values: faith value, ihsan (perfection) values, Islamic values, takwa (piety) value, sincerity value, tawakal (reliance) value, gratitude value, and patience value. Of these eight values, if applied in daily life, inshallah they will make us human with dignity."

The first value in the Anbiya book is faith value. According to Rice and Al-Mossawi in Ezzi et al. (2014), one feature that distinguishes believers of Islam from the believers of different faiths is that through a way of means of the Qur'an faith which is a crucial part of the lifestyle of all Muslims. In Nurhadi (2019), faith is to justify with the heart, speak with words, and do with deeds. The faith value is shown at the opening of the Anbiya book reading to be grateful for the blessings given by God Almighty. Moreover, the reader believes that all the blessings given are a blessing from Allah SWT. That way, the value of faith in the Anbiya book reading tradition already exists. Apart from that, the reader believes in the existence of prophets sent by Allah SWT, the books sent down by Allah SWT, and all of the Oneness of Allah. This faith value is shown in the first part of the Asmarandana stanza, which reflects the attitude and nature of believing in God Almighty with praise and prayer addressed to Allah. Likewise, faith in the prophet and the prophet's companions is poured out in it.

The second value of the Anbiya book is Islamic value. Religion is one of the most influential social establishments, which is extensively related to people's attitudes, values, and behaviors (Rafiki \& Wahab 2014). The research of Asraf (2014), Amaliah et al. (2015), and Hiyoda et al. (2021) explained that religiosity is one's attitude towards religion in general, not only one aspect of religion, but also the intensity of one's way to become a religious. Islam comes from Arabic which etymologically means prosperous, not disabled, safe. Meanwhile, the definition of Islam according to the terms is the attitude of surrender (resistance, submission, obedience) of a servant to their Lord by continuing to execute commands and avoid His prohibitions in order to achieve peace and safety of life, in this world and the hereafter (Nurhadi 2019). The Anbiya book reading tradition is an acculturation of tradition between Islamic culture and Javanese culture. Therefore, it has Islamic values. Someone who reads the Anbiya book admits that they have one God, that is Allah SWT. With this recognition, they will leave over all the paths given by Allah SWT so that they can surrender and accept all destiny. By surrendering, the safety of life, which is the essence of Islam's meaning, will always accompany life. This Islamic value is manifested through the $64^{\text {th }}$ verse of the Pangkur song, which tells the Prophet Muhammad's story during the Khondak war.

The third value is ihsan value. Ihsan is an Arabic word that means "perfection" or "excellence". In Islamic terminology, Ihsan means a person who worships Allah as if they see Him. If they are unable to imagine seeing Him, that person imagines that Allah sees their actions (Amran 2012). The Anbiya book reading tradition tells good things and bad things through the prophet's stories and the prophet's companion's stories. The good behavior and action stories of the Anbiya book reflect the perfection values. Furthermore, from the good actions or akhlakul karimah, the Anbiya book readers try to apply them in everyday life. Ihsan comes from the Arabic hasan, which means beautiful or suitable and proper or right (Mastura \& Yusof 2019). Based on Ibn Manzur in Mastura \& Yusof (2019), perfection implies the importance of virtue, good deeds, and compassion. According to Mastura \& Yusof (2019), perfection creates extreme dedication in personnel without which they might by no means moving past their assigned duty to perfect their jobs. Through the Anbiya book reading tradition, they preach to spread the goodness shown to the broader community. The nature of the prophets and apostles who used them as examples does expect to elevate religious activity's value into the wider community's life. The part of the $40^{\text {th }}$ verse of the Pangkur song, which tells of when the Prophet Musa does slander by Korun, gives an example of the nature of perfection that Prophet Musa possessed.

The fourth value is takwa value. Takwa (piety) is the method of stopping God's punishment through averting what God has forgiven and following God's commands (Al-Sharawi in Maham \& Bhatti 2019). Piety is interpreted as simple terms as the human attitude to constantly aware that Allah SWT is always watching everything humans do. Through the example of the Prophets and the Apostles of Allah SWT, piety applies in the Anbiya book reading. The guidance that has meaning in the Anbiya book to always 
fear God Almighty must be run by the Anbiya book readers and local communities. Piety is expecting to be absorbed in the religious and social life of societies. The piety value is explained in the $67^{\text {th }}$ stanza of the Sinom song, which tells about Prophet Muhammad's character and personality, flawless or without ugliness. Through the example of the prophets' devotion, da'wah imitates this attitude intensively reading Anbiya book to make people live in harmony and tolerate others.

The fifth value in this tradition is sincerity value. According to Riadi \& Emzir (2015), sincerity is a blessing from Allah, of which purpose relies upon human willingness. Sincerity is an act that is merely for Allah SWT's sake. It is actions that are done only for Allah SWT's pleasure and only with His blessing will end with beneficial blessings in the world and the hereafter. The sincerity value in the Anbiya book reading is a natural manifestation of sincerity, which actualizes in the Anbiya book reading and daily life. The $40^{\text {th }}$ stanza of the Pangkur song tells of the Prophet Moses's and Korun's teaching of the sincerity that every human being expects to be able to possess.

The sixth value is tawakal value. With the ability, humans will always lean back, full of hope and full of prayers, which all address Allah SWT. A human such that is called a resilient human. They are humans with resilient values in their religious life according to Islam. The Anbiya book describes examples of resilience attitudes, reflecting how the Prophet Sulaiman faced trials of Allah SWT. When he knew that all calamities were trials, he still hoped for the help of Allah SWT and all the solutions given by Allah SWT. The $51^{\text {st }}$ stanza of the Pangkur song tells when Prophet Sulaiman was subjecting to a trial and still resilient by the solution of Allah SWT. In the Anbiya book reading, we always hope that Allah SWT can help us find the best way to live. Resilience is a maximum level in the presence of God or function to gain the God closer. Resilience, according to Al-Ghazali in Riadi \& Emzir (2015), is frequently visible because of the end result of tauhid. In other words, tauhid features as a basis or primary of tawakal. Tawakal depends on our coronary heart to Allah with the aid of using believing in Allah hopefully, with the notice to break out from every other supervision or sources (Riadi \& Emzir 2015).

The seventh value of the reading of Anbiya book is gratitude value. Gratitude which is always direct to Allah SWT, is an obligation for us as humans. This gratitude application is full of colors and expressions. Pray is the primary and first form of gratitude to Allah SWT. There are several other ways. The virtue of gratitude is very much related to the love of Allah SWT. If we are grateful, we will surely love Allah because of all His benefits and if we love Allah, we will believe and obey Him. (Mohammad 2010). Gratitude is using God's blessings as they are intended when they are created. Gratitude is the key to grace and self-worth and draws people to God (Hosseini et al. 2016). The Anbiya book reading has the essence of continually giving thanks and applying it in everyday life. Through the Anbiya book reading, gratitude is created and expressed through Javanese songs that breathe Islam. The value of gratitude is written in the pambuka song of the Anbiya book, which reflects gratitude.

The last value is patience value. Patience is a responsible attitude in facing all the trials of life, both big and small, physically and mentally, physiologically and psychologically. According to El Hafiz in Rusdi (2016), patience has five dimensions: 1) being optimistic in dealing with all problems; 2) being unyielding in solving problems; (3) having a spirit of seeking out knowledge and information; (4) having a spirit of finding solutions and alternatives; and (5) being persistent. Patience in Islam entails a sense of knowing that Allah SWT is surely going to help one when they are struggling with a challenging situation, yet remain calm and tenacious. As described, the prophets were steadfast in facing all the trials given by Allah SWT (Salleh et al. 2020). Thus, it encourages readers of the Anbiya book to be patient and resilient in every trial they face. The Anbiya book describes the form of patience in the Prophet Muhammad's story in the $61^{\text {st }}$ verse of the Pangkur song when Abu Jahl threatened the Prophet Muhammad's life. Patience is the primary key to life, and that is what is tried to apply in the reading of Anbiya book. 


\section{Conclusion}

The Anbiya book reading tradition comes from Surakarta, which is acculturation between Islamic and Javanese cultures. The Anbiya book reading tradition is an activity of reading the Anbiya book using the macapat song as the reading tone. Besides, the Anbiya book reading tradition is one of the Indonesian culture's legacies in the Nglegok Sub-district. The Anbiya book reading tradition in Nglegok Sub-District is carried by the Syekh Subakir Association, which is formed in 2010.

The Anbiya book reading tradition has strong cultural and religious values, especially Islam. The religious values in the Anbiya book include: 1) The Anbiya book invites people to do good value in their daily lives; 2) Faith value is shown at the Anbiya book's opening, with the aim of saying gratitudes for the blessings given by God Almighty; 3) Islamic value is shown through acculturation between Islamic culture and Javanese culture; 4) Ihsan value, in the Anbiya book reading tradition, is shown through good things and bad things through the stories of the prophet and the apostles' companions; 5) Takwa value is defined simply as the attitude of humans to always be aware that Allah SWT are always watching what they do; 6) Sincerity value is act that is merely for the sake of Allah SWT and hopes for the pleasure of Allah SWT; 7) Tawakal value is a form of human being to always lean on, full of hope, and full of prayers, all of which are addressed to the God of the universe, that is Allah SWT; 8) Gratitude value is gratitude that is always addressed to Allah SWT; 9) Patience value is an attitude of steadfastness in facing all the trials of life given by Allah SWT, both great and small.

\section{References}

Amaliah I, Aspiranti T, \& Purnamasari P (2015) The impact of the values of Islamic religiosity to Islamic job satisfaction in Tasikmala West Java, Indonesia, industrial centre. Procedia - Social and Behavioral Sciences 21 (1):984-991. https://doi.org/10.1016/j.sbspro.2015.11.131.

Amran A (2012) Konsep adil dan ihsan menurut aqidah, ibadah dan ahlak. Hikmah. 6 (2):101-114.

Ananta A, Utami DRWW, \& Handayani NB (2016) Statistics on ethnic diversity in the land of Papua, Indonesia. Asia \& the Pacific Policy Studies 3 (3):458-474. https://doi.org/10.1002/app5.143.

Andewi S (2016) The internalization of Islamic values in Pesantren. Jurnal Pendidikan Islam 2 (3):430444.

Asfina R \& Ovilia R (2016) Be proud of Indonesian cultural heritage richness and be alert of its preservation efforts in the global world. Humanus 15 (2):195-206. https://doi.org/10.24036/ jh.v15i2.6428.

Asraf A (2014) Pengaruh kualitas produk terhadap keputusan menyimpan dana di Bank Muamalat Indonesia Cabang Pasaman Barat dengan religiusitas sebagai variabel moderator. e-Jurnal Apresiasi Ekonomi 2 (1):61-72.

Brandes JLA (1901) Beschrijving Der Javaansche, Balineesche En Sasaksche Handschriften, Part 1. Jakarta: Adigama-Ender.

Burhan \& Asmiraty (2019) The tradition of tahlilan on Ternate society. The International Journal of Social Sciences and Humanities Invention 6 (3): 5347-5354.

Dayakisni T \& Yuniardi S (2004) Psikologi Lintas Budaya. Malang: UMM.

Ezzi SW, Teal EJ, \& Izzo GM (2014) The influence values on connected generation students in Saudi Arabia. Journal of International Business and Cultural Studies 9:1-19.

Heriwati SH (2017) Imperative speech acts in Javanese songs. International Journal of Science and Research (IJSR) 6 (8):226-237.

Hiyoda FF, Muhdar, \& Sofhian (2021) Religiusity effect on retirees customer decisions in the takeover from conventional banks to Islamic banks: Study at Gorontalo City-Indonesia. International Journal of Social Science and Human Research 4 (2):191-198.

Hosseini L, Kashani FL, Akbari S, Akbari ME, \& Mehr SS (2016) The Islamic perspective of spiritual intervention effectiveness on bio-psychological health displayed by gene expression in breast cancer patients. Iranian Journal of Cancer Prevention 9 (2):e6360. https://doi.org/10.17795/ijcp6360 . 
Maham R \& Bhatti OK (2019) Impact of taqwa (Islamic piety) on employee happiness: A study of Pakistan's banking sector. Cogent Business \& Management 6 (1):1-22. https://doi.org/10.1080 /23311975.2019.1678554.

Mastura AW \& Yusof (2019) Mas'uliyyah and ihsan as high-performance work values in Islam. International Journal of Economics, Management and Accounting 27(1):187-212.

Mohammad AS (2010) Key concepts in Islamic spirituality: Love, thankfulness, and humbleness. A Quarterly Journal of Islamic Studies 11 (2):15-34.

Moleong LJ (2000) Metode Penelitian Kualitatif. Bandung: PT Remaja Posdayakarya.

Mu'adi S \& Sofwani A (2018) Acculturation of Islam and Javanese culture in public servant ethics. El Harakah 20 (2):233-252. https://doi.org/10.18860/el.v20i2.5355.

Ngabei Y (2010) Sekar Macapat Kitab Anbiya. Blitar: Al Ibrohimiyah Press.

Nurhadi (2019) Islam, iman dan ihsan dalam kitab matan Arba'In An-Nawawi: Studi materi pembelajaran pendidikan Islam dalam perspektif hadis Nabi SAW. Jurnal Intelektual 9 (1):1-18. https://doi. org/10.33367/ji.v9i01.811.

Setiyadi DBP \& Wiyono S (2017) Thematic multikultural texts: A study on building tolerance. In: The $10^{\text {th }}$ International Conference, 18 March, Salatiga. Indonesia: The $10^{\text {th }}$ International Conference, 41-62.

Rafiki A \& Wahab KA (2014) Islamic values and principles in the organization: A review of literature. Asian Social Science 10 (9):1-7. https://doi.org/10.5539/ass.v10n9p1.

Riadi S \& Emzir E (2015) Sufistic and transformative pedagogic values in Syaikh Siti Jenar Novel by Agus Sunyoto genetic structuralism. International Journal of Language Education and Culture Review 1 (1):78-86.

Rusdi A (2016) Patience in Islamic psychology and its measurement. Paper submission for The 3rd Inter-Islamic University Conference on Psychology: 1-14.

Saddhono K \& Pramestuti D (2018) Sekar Macapat Pocung: Study of religious values based on Javanese local wisdom. el Harakah 20 (1):15-32. http://dx.doi.org/10.18860/el.v20i1.4724.

Sahlan A \& Mulyono (2012) Pengaruh Islam terhadap perkembangan budaya Jawa: Tembang Macapat. el Harakah 14 (1):101-114. https://doi.org/10.18860/el.v0i0.2196.

Salleh K, Rahman AZ, AY Noor M, Kashim, Long AS, Hasan AZ, Ridzuan AR, Ismail S, Hamjah SH, Kadir MNA, Saari CZ, \& Farid M (2020) Resilience and patience (Sabr) in Islamic view when observing the movement control (Order MCO) during the Covid 19 pandemic. International Journal of Psychosocial Rehabilitation 24 (1):5485-5497.

Soerjono S (1982) Sosiologi Suatu Pengantar. Jakarta: CV Rajawali.

Suarta MI(2018) Nilai-nilai filosofs didaktis, humanistis, dan spiritual dalam kesenian tradisional Macapat masyarakat Bali. MUDRA Jurnal Seni Budaya 33 (2):191-199. https://doi.org/10.31091/mudra. v33i2.364.

Suradi A, Kenedi J, \& Surahman B (2020) Religious tolerance in multicultural communities: Towards a comprehensive approach in handling social conflict. Udayana Journal of Law and Culture 4 (2):229-245. https://doi.org/10.24843/UJLC.2020.v04.i02.p06.

Syafitri E, Rofiiqoh H, Alimah R, \& Chamdani M (2018) Character values in Macapat song. Social, Humanities, and Education Studies (SHEs) Conference Series 1 (2):166-174. https://doi. org/10.20961/shes.v1i2.26900. 